\title{
Cannulated Double-Threaded Compression Screw (Herbert-Type) Fixation for Displaced Odontoid Fracture
}

\author{
Yuji Handa, Hisamasa Ishii, Takao Nakagawa, \\ Hidetaka Arishima, Toshihiko Kubota
}

Department of Neurosurgery, Fukui Medical University, Fukui, Japan

\begin{abstract}
Direct anterior screw fixation of a displaced odontoid fracture (OF) has been indicated for reasonable method of treatment. We have experienced three cases of displaced $\mathrm{OF}$, in which fractured dens were fixed by one cannulated doublethreaded compression screw. We present cases, operative techniques and advantages of this type of screw in comparison with the cancellous bone screw used in our early cases. Two cases showed posterior-displaced Anderson Type II OF and one case showed anteriorly displaced shallow Type III OF. The head was retracted to be positioned with fracture-fragment alignment in the best possible reduction. Small part the antero-inferior portion of the dens body was drilled out. Under simultaneous antero-posterior and lateral fluoroscopic control, a guide pin was introduced to penetrate the cortex of distal end of the dens. Following the trajectory of the guide pin, drilling, tapping and then a screw implantation were manipulated. The double-threaded screw with pitch difference between the front and back threads produced compression force across the fracture line and thus rigid internal fixation. All cases showed excellent placement of screws and no nonunion during following period of 12 months. The present surgical method seems to be optimal for displaced OF rather than the anterior fixation method using conventional type of screw or posterior arthrodesis.
\end{abstract}

Key word: anterior screw fixation, cannulated double-threaded screw, odontoid fracture

Spinal Surgery $12(2): 145 \sim 152,1998$

\section{INTRODUCTION}

Odontoid fractures are common injuries, occurring approximately $10 \%$ of patients with cervical fractures [4]. Anderson and D'Alonzo classified the odontoid fractures into three types [2]. Of them, unstable Type II fractures through the waist of dens and displaced shallow Type III fractures have a poor prognosis, with a great chance of nonunion [2]. Because of the poor rate of healing in these types of odontoid fractures [2], they have been treated with various operative methods $[6,17,20]$ as well as nonoperative immobilization [21]. Although the previous physicians have recommended primary posterior $\mathrm{C} 1-\mathrm{C} 2$ arthrodesis as initial treatment for displaced odontoid fractures [8, 22], a number of methods for posterior arthrodesis have showed a disadvantage. Posterior arthrodesis leads to lose neck motion [16, 25], particularly in cases accompanied with $\mathrm{C} 1$ and $\mathrm{C} 2$ laminar or articular fractures in which posterior arthrodesis must be performed between occiput and $\mathrm{C} 2$ or 

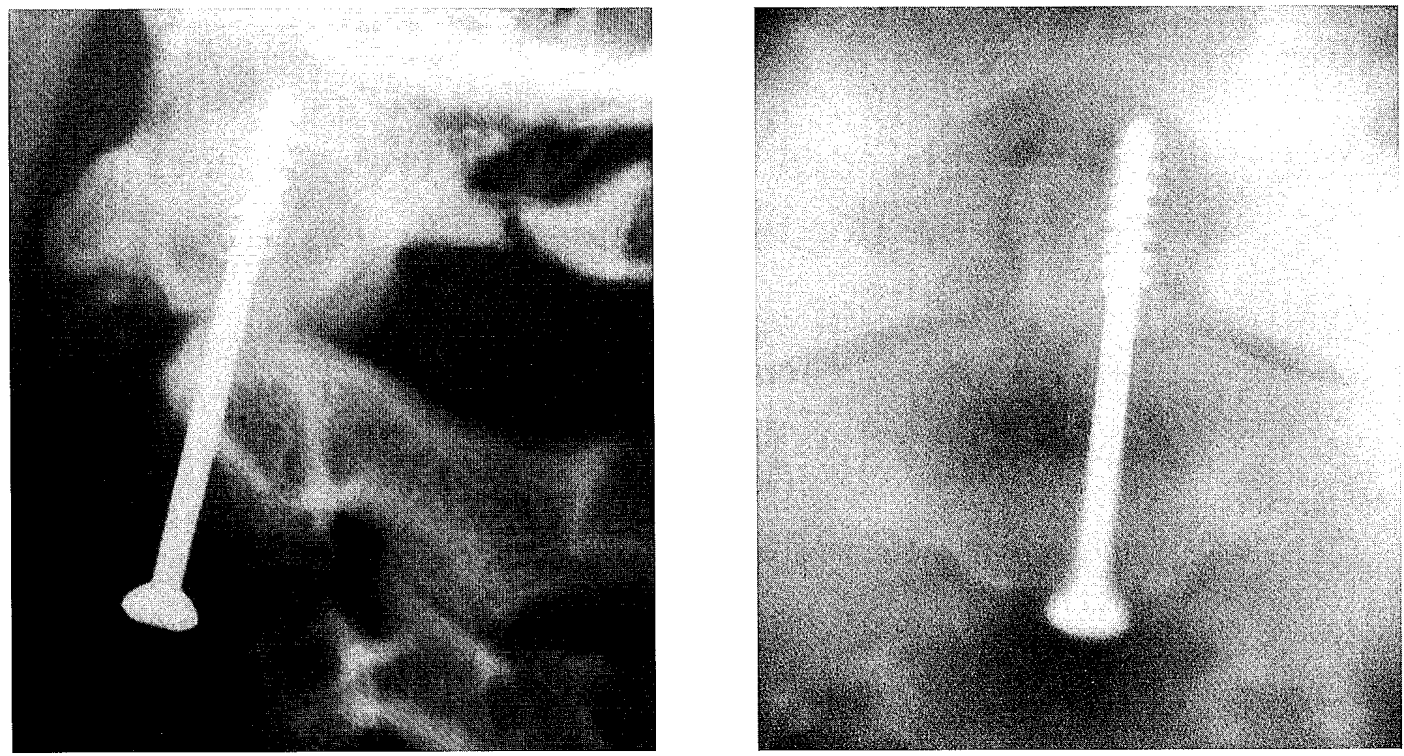

Fig. 1

Case 1: Postoperative roentgenograms show improper position of the screw and no tight reduction of the fractured line.

C3 lamina. On the contrary, direct anterior screw fixation of fractured odontoid via a transcervical approach has been employed for surgical stabilization with displaced or unstable fractures $[3,20]$. This technique is considered to be reasonable method of treatment with the advantage for the neck motion rather than the posterior arthrodesis [20], while the techniques for this anterior fixation seems to be relatively difficult than the standard posterior approach [1]. By now, several operating methods by a few types of screw system have been used for this anterior fixation of dens $[1,3,5,7,20]$. Of them, double-threaded compression screw (Herbert-type) has been reported to show some advantages compared to other types of screws [7]. Chang et al. [7] reported seven cases with displaced odontoid fractures fixed by a non-cannulated doublethreaded compression screw. Although they showed good prognosis with high union rate $(100 \%)$, the authors emphasized that this procedure requires thorough preoperative planning and adherence to technical details while they used noncannulated type. On the other hand, cannulated screw fixation technique using pre-positioned guide wire have been recognized to have some benefits and easiness in operative techniques for fixation of upper cervical fractures $[9,11]$. We have experienced five cases of displaced odontoid fractures. Fractured odontoid was stabilized by conventional cancellous bone screw in early two cases, and by cannulated double-threaded compression screw in recent three cases. We report here cases, detail of operative techniques and the advantages of a cannulated double-threaded compression screw fixation, in comparison with cancellous bone screw.

\section{MATERIALS AND METHODS}

\section{$<$ Fixation by cancellous bone screw >}

\section{Case report}

Case 1

A 26-year-old male complained severe neck pain following motor vehicle accident. The roentgenograms revealed shallow Type-III odontoid fracture with fracture of the posterior ring of atlas. The direct anterior fixation, by using a cancellous bone screw, was performed 10 days after accident. A screw of $40 \mathrm{~mm}$ length was inserted to penetrate the cortex of the distal end of the dens following drilling and tapping in the fractured bone segment under two direction fluoroscopy. Because the screw position was not placed in proper position and reduction of fracture line was not perfect on the postoperative roentgenograms (Fig. 1), the neck of the 

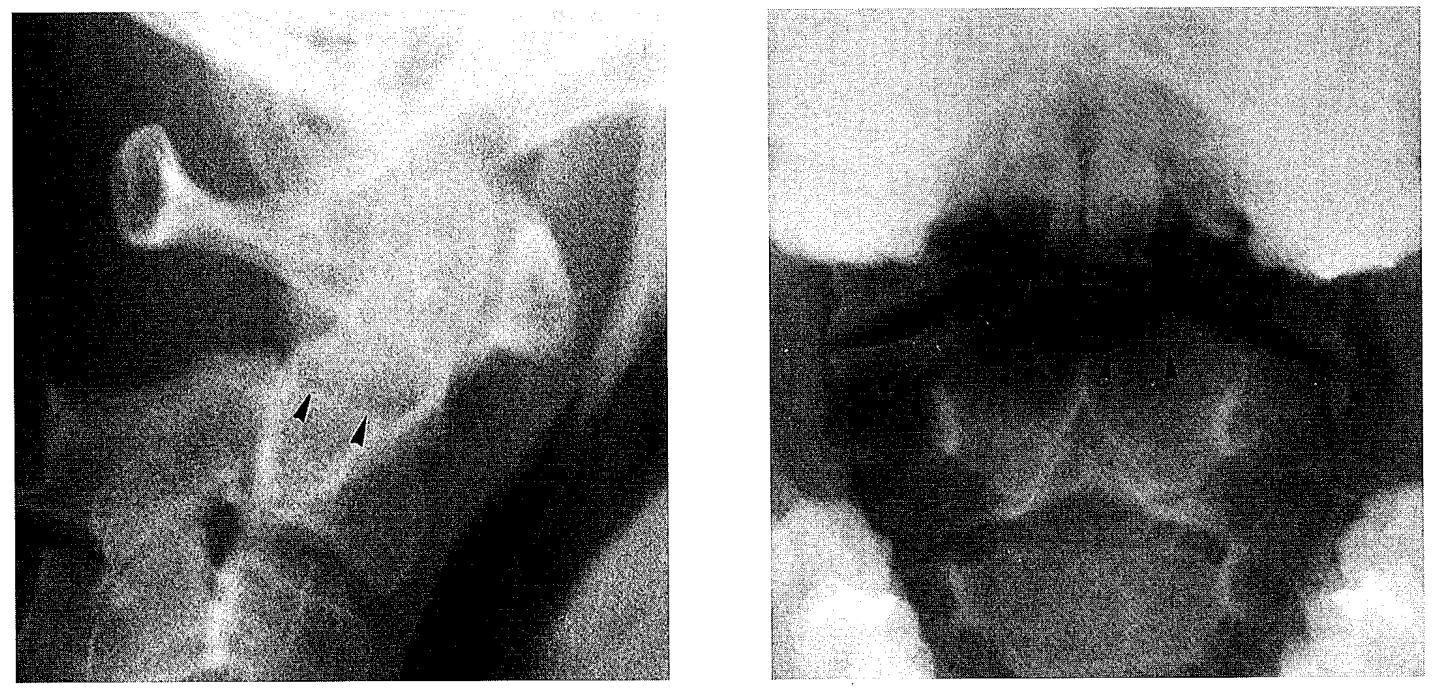

Fig. 2

Case 2: Preoperative roentgenograms show shallow type III odontoid fracture with anterior displacement of atlas. Arrow heads indicate fracture line.

patient was immobilized by Halo-pelvic apparatus for two months. The patient showed no symptom and returned to the previous work three months after the operation.

\section{$<$ Fixation by cannulated double-threaded bone screw >}

\section{Case reports}

Case 2

A 31-year-old man complained severe neck pain following motor vehicle accident. The roentgenograms showed shallow Type-III odontoid fracture presenting anterior displacement of atlas on flexion of the neck. At first, the neck was immobilized by Philadelphia neck collar and the direct anterior fixation was done two weeks after accident. (Fig. 2)

\section{Case 3}

A 77-year-old man showed tetraparesis following motor vehicle accident. The MRI revealed the spinal cord lesion at the C2 level. Roentgenograms revealed the Type-II odontoid fracture with posterior displacement of atlas on neck extension. At first, the head was tracted by GardnerWells tongs. After improvement of the physical conditions, the operative fixation was done three weeks after accident.

Case 4

A 68-year-old woman complained neck pain after fall from the height of $3 \mathrm{~m}$. The roentgenograms showed Type-II odontoid fracture with posterior displacement of atlas on extension and fracture of the posterior ring of atlas. The neck was immobilized with neck collar and the direct anterior fixation was performed 10 days after accident.

\section{$<$ Operative Technique >}

Nasotracheal intubation was performed to facilitate transoral image of the dens and fracture site during surgery. The patients was positioned supine, and the head was placed on a radiotransparent headrest. Under lateral fluoroscopy, the head and neck was extended and retracted by Gardner-Wells tongs to be positioned with fracture-fragment alignment in the best possible reduction and to provide the proper screw trajectory. Horizontal skin incision was placed over the level of $\mathrm{C} 4$ vertebral body, allowing room to angle the drill and screw nearly parallel to the anterior bodies. Routine dissection was 

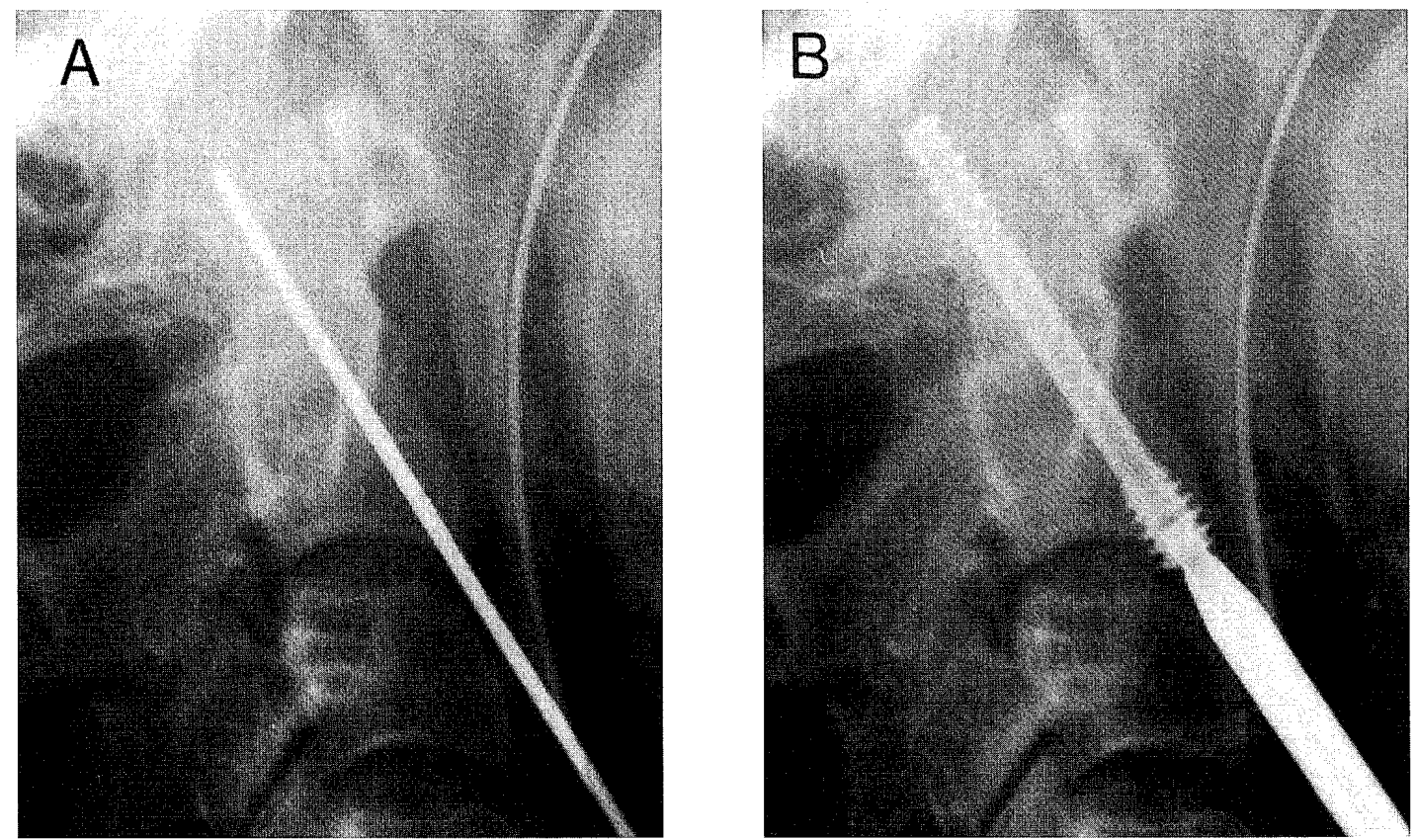

Fig. 3

A: Insertion of a guide pin to penetrate the cortex of the distal end of the dens.

B: Manipulation of a screw through the trajectory of the guide pin.

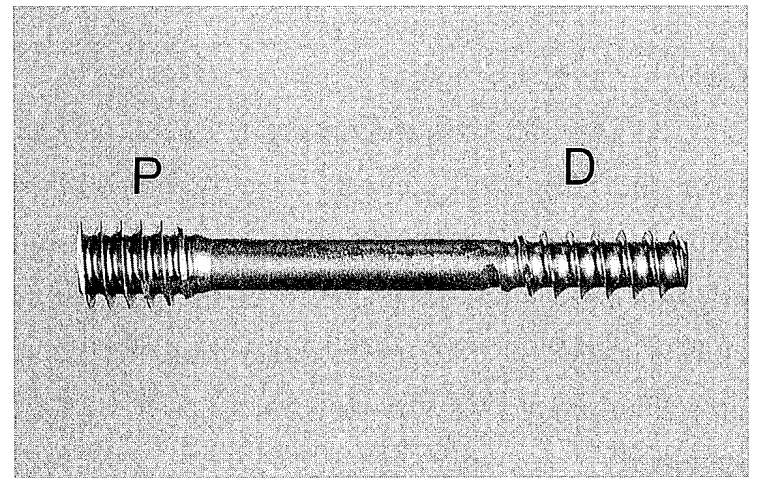

performed to expose the anterior surface of the vertebral body of $\mathrm{C} 4$, and then exposure was extended superiorly to the level of $\mathrm{C} 2 / 3$ intervertebral disc. The small square incision and partial discectomy was performed in the midline of the disc, and the screw entry site at the anterior inferior edge of the $\mathrm{C} 2$ body was drilled out. Simultaneous antero-posterior open-mouth and lateral image intensifier was mandatory to visualize the fracture site and the odontoid process during operative procedures. Under the fluoroscopic control, a guide pin was carefully inserted, at high-speed drill but with minimal axial pressure, to penetrate the posterior cortex

\section{Fig. 4}

We used a $40 \mathrm{~mm}$ length of screw. The screw has two pitch different proximal thread $(\mathrm{P})(1.35 \mathrm{~mm})$ and distal thread (D) $(1.75 \mathrm{~mm})$.

of distal end of the odontoid. (Fig. 3A) The guide pin is 1 $\mathrm{mm}$ in diameter and has a trocar tip to facilitate drilling into the bone. Broaching, drilling and tapping were performed over the guide pin by hand manipulation. Then, a double-threaded screw (The Cannulated Herbert Bone Screw, Zimmer, New York), $40 \mathrm{~mm}$ length, was implanted by hand manipulation.(Fig. 3B, 4) Under lateral fluoroscopy, the distal end of the screw was observed to penetrate the upper dorsal cortex of dens over the trajectory of the guide wire. Finally, the proximal thread end was screwed tightly to be embedded on the inferior margin of the $\mathrm{C} 2$ body. 

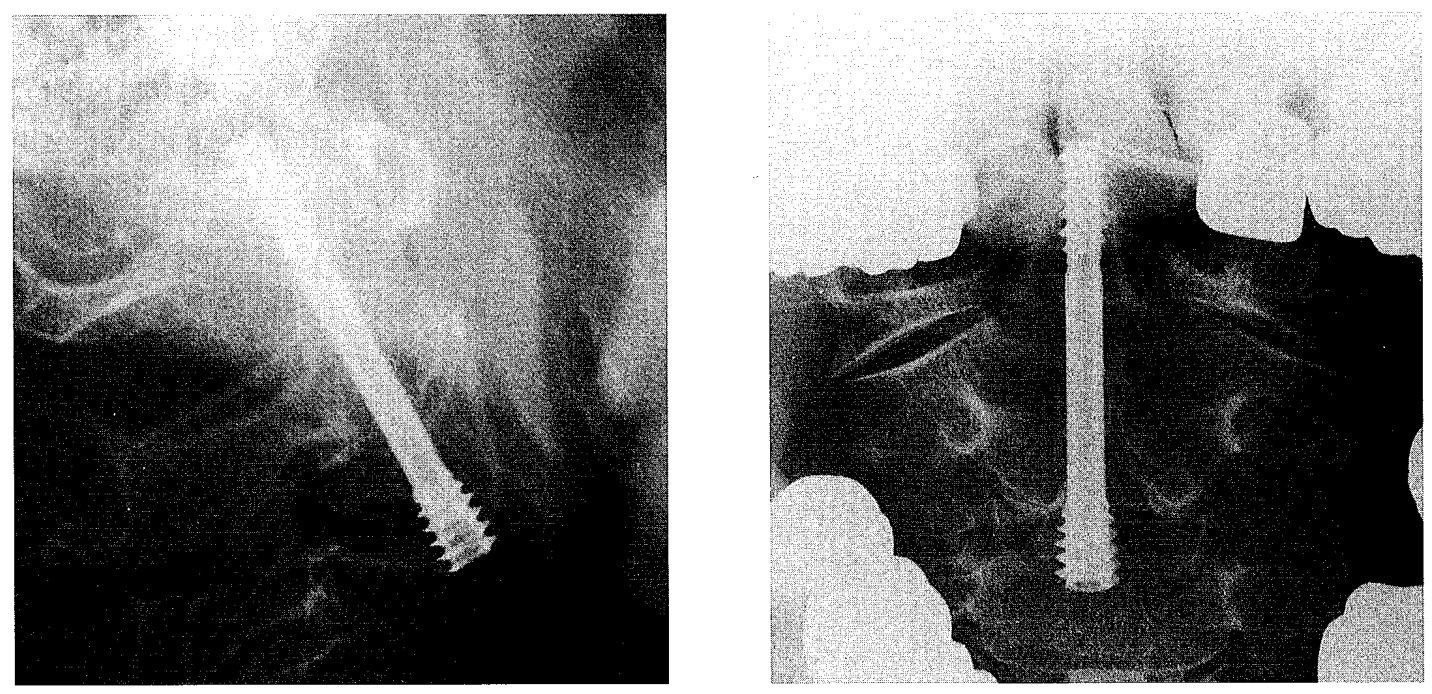

Fig. 5

Roentgenograms, at the following time of 12 months after operation in case 4 with type II odontoid fracture, shows good placement of screw and the union of fractured odontoid.

\section{RESULT}

In the patients fixed by a cannulated double-threaded screw, postoperative immobilization was achieved for 6-8 weeks by means of Philadelphia neck collar. In all the patients, roentogenograms showed excellent placement of all screws with tight reduction of fracture line without nonunion at the following time of 12 months. (Fig. 5) The old man suffering from cervical cord injury died resulting from respiratory failure 14 months after surgery. The other two patients returned to work and/or the activities of daily living.

\section{DISCUSSION}

The critical review article indicates that currently there are no treatment standards available to guide the care of unstable odontoid fractures [24]. Now, four treatment options do exist and the fusion success rate with each technique is nearly similar [24]: traction followed by immobilization in a cervical collar $[2,15]$, immobilization with a halo apparatus [21], posterior cervical fusion $[6,8,17,18,23]$, and anterior screw fixation $[1,3,5,7,14,19,20]$. As mentioned above, direct anterior screw fixation had been developed against significant loss of the neck motion produced by posterior arthrodesis. Nakanishi et al. [20] originally developed the anterior screw fixation in 1978. Because of not only the advantage for neck motion [20] but also less invasiveness of the operation and short immobilization period following surgery, this operative option was found to be useful specially in elderly or multiple trauma patients $[1$, $11,19]$. Despite of these advantages, the previous studies [1] revealed that the technique for anterior screw fixation seems to be quite difficult for unexperienced surgeons and that non-union rate was not smaller than other operative options.

Double-threaded screw (Herbert type) has been developed for fixation of small bone fractures in hand or foot surgery $[12,13]$. The screw has two pitch different, self cutting threads which are independently arranged along a slim, thread less center piece. Due to its steeper angle and the greater distance between the threads, the entry velocity of the distal thread is greater than that of the proximal thread. These characteristic structure of the screw leads the distal bone fragment to be moved toward the proximal bone fragment in the course of screw fixation, and produces compression force across the fracture and thus rigid internal fixation. (Fig. 4,6) On the contrary, conventional type of cancellous bone screw, as 


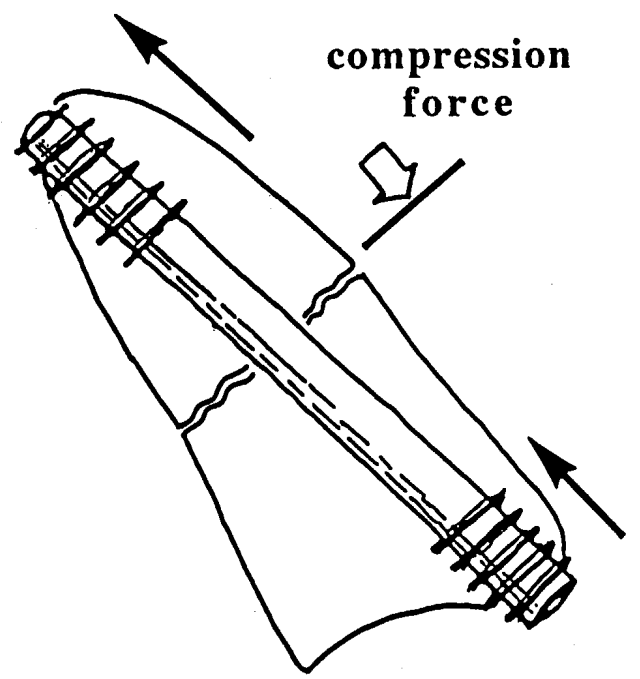

Fig. 6

This double-threaded screw shows pitch difference between the two thread, which has the effect of drawing together two bone fragments, producing compression force across the fracture line and rigid internal fixation.

used in our first case, may produce compression force between the screw head and the distal thread that must be penetrated to the distal cortex of the fragment. While anterior screw fixation by cancellous bone screws showed the nonunion in cases of more than $10 \%[11,14,19]$, the screw fixation by a double-threaded screw in the previous [7] and present studies showed no nonunion. In the present study, the reduction of the fracture line was relatively imperfect in cases treated with cancellous bone screw compared to cases with double-threaded screw. These results indicate that the compression force across the fracture line by double-threaded screw may be stronger than that by the other conventional types of screw. Furthermore, the double-threaded screw has no screw head. The distal end of the screw must be embedded tightly into the inferior surface of $\mathrm{C} 2$ body, and shows no protrusion resulting in minimal irritation to the adjacent tissues. Thus, the present double-threaded screw seems to show some advantages and less complications than other conventional type of screws.

Fracture fixation in the upper cervical injury have been performed by means of cannulated screw systems using their guide pin $[9,11]$. This operative method have showed several distinct advantages compared to the noncannulated screws. When the original trajectory of guide pin is not ideal, repositioning can be easily performed under image intensifier, and then the screw are easily positioned over properly inserted guide pin. The guide pin fixes continuous fixation of adjacent unstable bone fragments and prevents migration of unstable bone fragments during screw insertion, while bone fragments can easily move out the proper alignment when noncannulated screw is inserted without guide pin. In our case fixed by non-cannulated cancellous bone screw, the authors experienced difficulty for drilling, tapping and inserting a screw through a unstable fractured bone fragment (dens) to the proper position of the distal end of dens even under the fluoroscopic control. Thus, the most of the attention and the time during the operative procedures must be paid for only insertion of the guide pin through the proper trajectory. When the guide pin was positioned properly, the procedure of screw insertion seems not to be extremely difficult.

Previous literatures $[1,10,11]$ emphasized that operative procedure for anterior screw fixation of displaced odontoid fracture should be performed by only experienced surgeons with the appropriate surgical facilities with due regard to the nonunion and complications. While we have experienced only three cases, the present operative method of anterior screw fixation by using one cannulated double-threaded screw system seems to be easier and less complicated method compared to the previous methods, and most suitable operative option for unstable odontoid fractures.

\section{REFERENCES}

1. Aebi M, Etter C, Coscia M: Fractures of the odontoid process: Treatment with anterior screw fixation. Spine 14: 1065-1070, 1989

2. Anderson LD, D'Alonzo RT:Fractures of the odontoid process of the axis. J Bone Joint Surg 56A: 16631674, 1989

3. Böhler J: Anterior stabilization for acute fractures and non-unions of the dens. J Bone Joint Surg 64A: 18-27 1985

4. Böhler J: Fractures of the odontoid process. J Trauma 
5: 386-391, 1965

5. Borne GM, Bedou GL, Pinaudeau M, Cristino G, Hussen A: Odontoid process fracture osteosynthesis with a direct screw fixation technique in nine consecutive cases. J Neurosurg 68: 223-226, 1988

6. Brooks AL, Jenkin FB: Atlanto-axial arthrodesis by the wedge compression. J Bone Joint Surg 60A: 279284, 1978

7. Chang KW, Liu YW, Cheng PG, Chang L, Suen KL, Chung WL, Chen UL, Liang PL: One Herbert doublethreaded compression screw fixation of displaced Type II odontoid fractures. J Spin Disord 7: 62-69, 1994

8. Clark CR, White AA: Fractures of the dens. J Bone Joint Surg 67A: 1340-1348, 1985

9. Dickman CA, Foley KT, Sonntag VKH, Smith MM: Cannulated screws for odontoid screw fixation and atlantoaxial transarticular fixation.Technical note. J Neurosurg 83: 1095-1100, 1995

10. Esses S, Bendar DA: Screw fixation of odontoid fractures and nonunions. Spine 16: S483-485, 1991

11. Etter C, Coscia M, Jaberg H, Aebi M: Direct anterior fixation of dens fractures with a cannulated screw system. Spine 16: S25-S32, 1991

12. Filan SL, Herbert TJ: Herbert screw fixation of scaphoid fractures. J Bone Joint Surg Br 78: 517-518, 1996

13. Ford TC: The Herbert bone screw and its application in foot surgery. J Foot Ankle Surg 33: 346-354, 1994

14. Fujii E, Kobayashi K, Hirabayashi K: Treatment in fractures of the odontoid process. Spine 13: 604-609, 1988

15. Govender S, Grootboom M: Fractures of the dens. The results of non-rigid immobilization. Injury 19: 165-167, 1988

16. Lysell E: Motion in the cervical spine. An experimental autopsy specimens. Acta Orthop Scand (suppl) 123: 1-61, 1969

17. Magerl F, Seeman P-S:Stable posterior fusion of the atlas and axis by transarticular screw fixation, in Kehr P, Weidner A (eds): Cervical Spine I. Berlin, Springer-Verlag, 1987, p332

18. Marcotte P, Dickman CA, Sonntag VKH, Karahalios DG, Drabier J: Posterior atlantoaxial facet screw fixation. J Neurosurg79: 234-237, 1993

19. Montesano PX, Anderson PA, Schlehr F, Thalgott JS, Lowrey G: Odontoid fracture treated by anterior screw fixation. Spine 16 (suppl): S33-S37, 1991

20. Nakanishi T, Sasaki T, Tokita N, Hirabayashi K: Internal fixation for the odontoid fracture. Orthop Trans 6: 176, 1982

21. Schwiegel JF: Halo-thoracic brace in the management of odontoid fractures. Orthop Trans 3: 216, 1979

22. Southwick WO: Management of fractures of the dens (odontoid process). J Bone Joint Surg 62A: 482-486, 1980

23. Stillerman CB, Wilson JA:Atlanto-axial stabilization with posterior transarticular screw fixation: technical description and report of 22 cases. Neurosurgery 32: 948-954, 1993

24. Traynelis VC: Evidence-based management of Type II odontoidfractures.Clin Neurosurg 44: 41-49, 1997

25. White AA, Panjabi MM: Kinematics of the spine: Clinical Biomechanics of the Spine. Philadelphia, JB Lippincott, 1978, pp65-66 


\section{Reviewer's comment : \\ Tatsuo Takahashi \\ Department of Neurosurgery, Nagoya National Hospital \\ Nagoya, Japan}

This article describes a good method to promote an original healing of the odontoid fracture of Type III of Anderson-d'Alonzo.

This method has an advantage to preserve a rotatory movement between $\mathrm{C} 1$ and $\mathrm{C} 2$, comparing to posterior $\mathrm{C} 1$ and $\mathrm{C} 2$ fusion which restricts all movements.

Christian Etter, et al. have used two cannulated screws to avoid a freed bony fragment to rotate and to redislocate. But Dickman, et al. have mentioned to use only one cannulated screw system without significant complications.

In future, the difference of fusion rate between these two methods must be studied in accumulated cases.

\section{Reviewer's comment：坂 本 博 昭（大阪市立総合医療センター 脳神経外科）}

著者らは歯突起骨折に対し, 前方からscrewによって分離した歯突起を固定する際， cannulated doublethreaded screw（Herbert type）を用いています。このscrewは, 骨折変位した歯突起と歯突起起始部とを密着 させることによって, 癒合不全の率を減少させる効果があり, またscrewの内部が中空であるため, 適切な位置 に刺入されたguide pinを通してこのscrewを刺入できることから，従来のscrewよりも技術的に容易であるとし ています，今回はこの方法を用いた症例数は少ないので，今後症例を重ねてさらにこの手術方法の確立を期街い たします。 